\title{
DESCRIPTIONS OF NEW HYMENOPTERA, NO. 4.
}

\section{By J. C. Crawford,}

Associate Curator, Division of Insects, United States National Museum.

Many of the new species described in this paper are from a collection sent for determination by Mr. L. C. Coleman, entomologist to the Government of Mysore, India. The microhymenoptera of that region are practically unknown and most of the species sent by $\mathrm{Mr}$. Coleman are new.

\section{Superfamily PROCTOTRYPOIDEA.}

\section{TELENOMUS COMPEREI, new species.}

Female.-Length, about $0.9 \mathrm{~mm}$. Black, legs fulvous, coxæ black; scape and pedicel about the color of the legs, rest of antennæ dark brown; articulating joint at base of scape long, black; first joint of flagellum slightly longer than pedicel, the pedicel elongate; face finely rugulose, lower part of face finely, closely punctured; head thin anterio-posteriorly, slightly wider than thorax; mesoscutum and scutellum rather coarsely reticulately rugulose; scutellum at apex with a single row of pits; metanotum covered by a single row of pits coarser than those on scutellum; first segment of abdomen at base with a row of pits, back of these, rugulæ, reaching to apex of segment; second segment about twice as wide as long, basally with a row of pits and back of this (except laterad) rugulæ reaching almost to apex of segment; following segments only showing slightly.

Male.-Length, about $0.9 \mathrm{~mm}$. Similar to the female, pedicel short, antennæ fulvous (the apical joints missing).

Habitat.-Canton, China.

Type.-Cat. No. 14338, U.S.N.M.

Seven females and one male reared from the eggs of an unknown hemipteron by Mr. George Compere, after whom it is named.

The coarse sculpture of the mesonotum distinguishes this species from the other species of the genus described from the Orient.

Proceedinas U. S. National museum, Vol 42-No. 1880.

20441 ${ }^{\circ}-$ Proc.N.M.vol.42-12-1 
TELENOMUS COLEMANI, new species.

Female.-Length, about $1.1 \mathrm{~mm}$. Black, the antennæ brown, the legs testaceous, the coxæ black; face granular; head transverse; pedicel and first joint of funicle subequal, second joint longer than wide, the following joints subquadrate, the club six jointed; mesoscutum finely reticulately rugulose, scutellum indistinctly reticulated, more apparent along anterior margin, opaque; metanotum with a transverse row of pits; first abdominal segment rugose almost the entire length; second segment with a basal row of pits, back of these rugæ which medially extends half the length of the segment; second segment wider than long (as $18: 13$ ).

Male.-Length, about $1 \mathrm{~mm}$., antennæ about $1 \mathrm{~mm}$. Similar to the female, the antennæ testaceous, the pedicel almost globular, the first three segments of the funicle elongate, the following ones subquadrate; the apical one about as long as the first.

Habitat.-Hunsmanalli, Mysore, India.

Type.-Cat. No. 14339, U.S.N.M.

Five females and one male reared from the eggs of Dolycoris indicus and sent by Mr. L. C. Coleman (for whom is is named) under his number $136 a$.

\section{HADRONOTUS FULVIVENTRIS, new species.}

Female.-Length, about $1 \mathrm{~mm}$. Head and thorax black, abdomen ferruginous, legs reddish testaceous, the coxæ and the front femora on basal two-thirds black; scape testaceous, the upper side medially brownish; rest of the antennæ reddish brown, the club more brown; pedicel slightly longer than first joint of funicle, following joints of funicle subquadrate; club 6-jointed, each subquadrate; face finely reticulated; mesoscutum finely rugulose, at rear medially becoming distinctly longitudinally so; scutellum longitudinally rugulose, at apex with a row of pits; metathorax with a row of pits and medially at apex with an elevated disk which is longitudinally rugulose; truncation of propodeum with rugulæ diverging from the center; mesopleuræ with a row of pits at front and one at rear, the rest of the surface rugulose; metapleuræ with a row of pits at front; marginal vein somewhat longer than pedicel of antennæ; stigmal almost twice as long as marginal; postmarginal over twice as long to stigmal; first abdominal segment with a row of pits at base, back of these, longitudinally striate, the apical margin smooth; second segment with a row of pits at base, back of this with fine reticulations, almost resembling shallow thimble-like punctures; broad apical margin of the second segment, smooth; following segments with similar punctures and broad smooth apical margins.

Male.-Length, about $1 \mathrm{~mm}$. Similar to the female, but the abdomen black; antennæ, except scape, brown, the pedicel slightly 
longer than the first joint of the funicle, the following joints subquadrate, the apical joint almost as long as the two preceding joints united; sculpture somewhat stronger than in female; middle and hind legs slightly suffused with brown toward base.

Habitat.-Bangalore, Mysore, India.

Three females and six males reared from the eggs of Clavigralla gibbosa and sent by Mr. Coleman under his number 129.

Type.-Cat. No. 14340, U.S.N.M.

\section{Superfamily CHALCIDOIDEA.}

\section{Family AGAONIDA.}

\section{Genus EISENIELLA Ashmead.}

Eiseniella Ashmead, Proc. Ent. Soc. Wash., vol. 8, 1906, p. 31. (New name for Eisenia Ashmead preoccupied.)

Secundeisenia Schulz, Spolia Hym., 1906, p. 146.

Allopade Strand, Archiv. f. Naturgesch., vol. 77, 1911, Heft 1, p. 210.

\section{Family TORYMIDÆ.}

\section{Tribe MEgastigMnN.}

In the Proceedings of the Entomological Society of Washington (vol. 12, 1910, p. 93), I called attention to the fact that Dr. Gustav Mayr had long ago corrected the error in regard to the number of spurs on the hind tibiæ in this tribe, but that this correction had been ignored. A reexamination of specimens of the type-species of the genus Megastigmus determined by Doctor Mayr, as well as all other species of the genus examined by me, show two well-developed spurs on the hind tibiæ. As the tribe Pulvilligerini Strand was erected because of two apical spurs (and the supposed absence of one in the Megastigmini) it appears to be a synonym.

\section{Tribe PODAGRIONINI.}

PODAGRION GREENI, new species.

Female.-Length, $4 \mathrm{~mm}$.; ovipositor, $8 \mathrm{~mm}$. Head and thorax green, the latter more bronzy and posteriorly more bluish, closely punctured, on the lateral areas of mesonotum and axillæ becoming almost transverse striæ; posterior part of scutellum finely reticulated; antennæ testaceous, the club brown, without a ring joint (see fig. 1); the club greatly enlarged, with a flattened sensory area on one side,

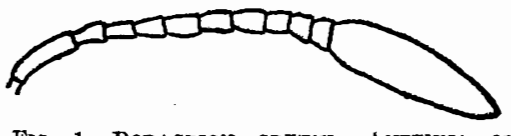

Fig. 1.- Podagrion greeni. Antenna of FEMALE. on the other, the sutures visible; mesepisternum above, punctured, below, together with the metapleuræ, reticulated; mesepimeron smooth; propodeum finely closely transversely striate, laterally 
becoming almost thimblelike punctures; no median nor V-shaped carina on propodeum, but just cephalad of insertion of abdomen a semicircular carina surrounding the posterior area of propodeum; wings subhyaline, with a small infuscated stigmal spot; front and middle legs, including coxæ, testaceous; posterior coxæ bluish, elongate, subcylindrical, as long as their femora; hind femora and tibiæ brown, the tarsi testaceous; hind femora with about 9-10 teeth, two or three of them being mere tubercles; abdomen petiolate, the petiole almost half the length of the hind coxæ; abdomen brown, the base lighter, the petiole more reddish.

Male.-Length, $4 \mathrm{~mm}$. Similar to the female, the antennæ entirely reddish testaceous; the thorax more greenish, the hind femora and tibir somewhat darker, the petiole shorter, the sculpture of the propodeum more like transverse rows of punctures.

Habitat.-Punduloya, Ceylon.

Five females and one male reared from egg capsule of Mantis, sp. by Mr. E. Ernest Green, after whom the species is named.

Type.-Cat. No. 14341, U.S.N.M.

\section{PODAGRION KOEBELEI, new species.}

Female.-Length, $4 \mathrm{~mm}$; ovipositor, $8 \mathrm{~mm}$. Green, the venter testaceous; the antennæ brown, with a ring joint, the scape at base in front testaceous, the club not enlarged (see fig. 2); head and thorax closely punctured, the punctures on the median lobe of the mesoscu-

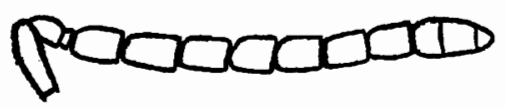

Fig. 2.-Podagrion kotbelei. ANtenNa of, TEMALE. tum thimblelike; those on the apical part of the scutellum finer than in the anterior part; lateral lobes of mesoscutum reticulated, along the inner margins almost transversely striate; propodeum punctured, with a median longitudinal carina which extends backward to about middle of propodeum where it divides each branch running laterad and slightly caudad; laterally these branches each join a longitudinal carina which extends from the apex of the propodeum almost to the anterior margin; back of the transverse carina are several irregular rugæ; coxæ, front and hind femora, except bases and apices, metallic; rest of legs reddish testaceous more or less suffused with brown; hind coxæ elongate, somewhat thickened basally; hind femora with about six teeth; mesepisternum punctured, upper section of mesepimeron faintly lineolate, lower section distinctly so; metapleuræ reticulately rugulose; abdomen subsessile. Male.-Length about $2.5 \mathrm{~mm}$. Very like the female except in secondary sexual characters.

Habitat.-Australia.

Many specimens reared from a mantid egg mass by Mr. Koebele (after whom the species is named) and with his note number 606, the note saying they came from South Australia. 
Type-Cat. No. 14342, U.S.N.M.

Differs from the description of obscurus Westwood in color and in the apex of the antennæ being concolorous with the rest, in the darker legs, etc., from that of olenus Walker in the dark antennæ and the color.

Specimens which I consider olenus Walker are without the lateral carinæ on the propodeum.

\section{PODAGRION RÉPENS Motschulsky.}

Female.-Head and mesonotum with shallow almost thimblelike punctures; mesopleuræ with similar punctures, the posterior half with finer ones; metapleuræ horizontally striate; propodeum with an inverted V-shaped carina, the surface with fine thimblelike punctures; posterior coxæ about as long as their femora, the basal end swollen; abdomen subsessible; antennæ with one ring joint and the club not greatly swollen.

The type consists of about 20 specimens on one card, and the above notes are from the type-material.

\section{Family MISCOGASTERID压.}

\section{Genus LELAPS (Haliday) Walker.}

Laelaps Dalld Torre, Cat. Hym., vol. 5, 1898, p. 184.

Dilaelaps Schulz, Spolia Hym., 1906, p. 144.

Stenopisthia Strand, Societas Ent., vol. 25, 1910, p. 25.

The two original references to this genus are: Walker in Ann. and Mag. Nat. Hist., vol. 12, 1843, p. 47, and Haliday in Trans. Ent. Soc. Lond., vol. 3, pt. 4, p. 299,. said to have been issued in 1843 . However, on page 237 of that volume, there is a footnote dated July 14, 1844, and the receipt of part 4 was acknowledged by the Entomological Society of France at the meeting of September 10, 1845 , so that this part must have been issued after July, 1844, and in all probability was not published until the beginning of the year 1845. It appears that the genus should be credited to Mr. F. Walker.

In both of these places the name is spelled Lelaps, and this spelling was changed to Laelaps by Dalla Torre. It is this latter spelling which is preoccupied, and the names proposed by Schulz and Strand are therefore unnecessary.

\section{Family ENCYRTIDA.}

ANASTATUS VUILLETI, new specles.

Female.-Length $2.25 \mathrm{~mm}$. Head varying shades of blue and green, thorax very dark blue-green, in some lights appearing black, or violaceous; abdomen aeneous; apical half of scape testaceous, the basal portion metallic; pedicel metallic green, rest of antennæ brown; 
pedicel longer than joints 1-3 of funicle combined, these joints subquadrate; face as high as antennal fossa granular, above this shining, indistinctly sculptured; median lobe of mesoscutum, lateral lobes in part, axillæ and scutellum reticulated with fine impressed lines; scutellum at base with two triangular depressed areas (adventitious ?); mesopleuræ and prepectus finely lineolated; femora green, tibiæ dark brown, anterior tibiæ in front and their tarsi testaceous; middle and hind tarsi at base as dark as their tibiæ; wings smoky, with hyaline bases and at apical half of marginal vein a hyaline area extending backward somewhat more than the length along marginal vein; on caudal margin of fore wing almost opposite this hyaline area, but slightly more toward apex of wing, another somewhat smaller hyaline spot; infuscation beyond end of marginal vein lighter than basad of this point; submarginal vein longer than the marginal and postmarginal combined; marginal vein somewhat longer than postmarginal, this in turn slightly longer than stigmal; abdomen finely reticulated with impressed lines.

Male.-Length about $2 \mathrm{~mm}$. Similar to the female, the head and thorax green, the scape entirely testaceous, sculpture of face stronger, that above antennal fossa almost as strong as below, but more like reticulations; sculpture of mesonotum stronger than in female; wings with an infuscated spot covering stigmal vein and extending about half way across wing; near apex of submarginal vein a small indistinct infuscated spot; front and middle legs, including apices of coxæ, testaceous; front femora with a green stripe behind; front tibiæ, middle femora and middle tibiæ with a brown stripe behind; hind legs dark brown, the femora and tibiæ with a narrow testaceous stripe in front; first, fourth, and fifth joints of hind tarsi dark brown, joints 2 and 3 , whitish.

Habitat.-Koulikoro, French Soudan, Africa.

Type.-Cat. No. 14343, U.S.N.M.

Eight females and five males reared from the eggs of Cerina butyrospermi Vuillet by Mr. Jean Vuillet, in whose honor the species is named; sent by Mr. A. Vuillet of the Entomological Station of the University of Rennes, France.

The species is peculiar in having the mesonotum entirely without thimble-like punctures.

\section{ANASTATUS COLEMANI, new species.}

Female.-Length about $3.5 \mathrm{~mm}$. Head green, the face metallic reddish; punctured portion of median lobe and lateral lobes of mesoscutum bronzy, rest of median lobe bluish-green; scutellum bronzy; rest of thorax and legs varying shades of bronzy or purplish; knees, tarsi, and anterior and middle legs in front reddish testaceous, the middle legs less so than the anterior; abdomen aeneous with a white band near.apex of first segment; face below antennæ roughened and laterad, granular; above, reticulated with impressed lines; scape 
testaceous, pedicel greenish, basal joints of funicle aeneous, rest of antennæ brown; pedicel hardly twice as long as broad; first joint of funicle almost twice as long as pedicel; 2-5 joints successively decreasing in length, joints 6 and 7 subquadrate; club about as long as first joint of funicle; median and lateral lobes of mesoscutum finely reticulated with impressed lines, the former at rear with shallow crowded punctures; scutellum and axillæ with thimble-like punctures; mesopleurae finely striate with impressed lines; wings dusky with hyaline bases and a curved hyaline band about middle of marginal vein, this band about as wide as the length of the stigmal vein, the concave side outward; marginal vein almost as long as the submarginal, postmarginal about half as long as marginal, stigmal less than half as long as postmarginal; abdomen short, the dorsum lineolate.

Male.-Unknown.

Habitat.-Bangalore, Mysore, India.

Two specimens reared from the eggs of Degonetus serratus and sent by Mr. L: C. Coleman (for whom the species is named) under his number 118.

In size and general appearance this species resembles $A$. stantoni Ashmead from the Philippine Islands, but that species is much greener and has the median lobe of the mesoscutum with thimblelike punctures.

Type.-Cat. No. 14344, U.S.N.M.

\section{Family EULOPHID $Æ$. \\ Subfamily FNTHDONIN AE. \\ PLEUROTROPIS FOVEOLATUS, new species.}

Female.-Length about $1.25 \mathrm{~mm}$. Deep purplish æneous with the propodeum and the base of the abdomen green; antennæ brown, more or less metallic; face above insertion of antennæ, both above and below V-shaped furrow, and median lobe of mesoscutum reticulately rugose; lateral lobes of mesoscutum with similar but less distinct sculpture and caudad, smooth; median lobe at apex longitudinally rugose and with two large fover; scutellum with the basal half Iongitudinally rugose, the apical half with large reticulations; propodeum polished, with two well separated medial carinæ and the lateral carinæ distinct; legs metallic, in part brown, the tarsi whitish.

Male.-Length about $1 \mathrm{~mm}$. Similar to the female, the head green, face purple; sculpture of the face not so strong as in female.

Habitat.-Bangalore, Mysore, India.

Two females and two males reared from larvæ of Epilachna vigintioctopunctata and sent by Mr. Coleman under his number 134.

This species has the mesoscutum biforeolate as in $P$. bifoveolatus Ashmead, but that species has the mesoscutum transversely rugulose.

Type.-Cat. No. 14345, U.S.N.M. 
Subfamily THTRASTICHIN AE.

\section{Genus TETRASTICHUS Haliday.}

Key for the separation of the females of some Oriental forms.

1. First joint of funicle hardly longer than the pedicel; coxæ testaceous, colemani Crawford.

First joint of funicle about twice as long as pedicel; coxæ dark............ 2

2. Propodeum between lateral carinæ with thimblelike punctures.echthrus Crawford.

Propodeum between lateral carinæ without thimblelike punctures....... 3

3. Legs whitish testaceous.............................. philippinensis Ashmead.

Legs with femora brown................................. ophiusæ Crawford.

TETRASTICHUS COLEMANI, new species.

Female.-Length about $1.8 \mathrm{~mm}$. Green, the abdomen apically brown; scape and legs, including coxæ, testaceous; rest of antennæ light brown; first joint of funicle only slightly longer than pedicel, joints two and three about as long as first; club almost as long as 1-3 united; face finely, indistinctly lineolate, smoother medially and below; between eyes and mouth parts the lineolation reticulated; along inner orbits a few scattered large punctures; mesoscutem and scutellum finely longitudinally lineolate, the furrows distinct; metanotum a transverse strip; propodeum with the median and lateral carinæ strong; between them with crowded very shallow punctures; prepectus and metapleuræ with thimblelike punctures; mesopleuræ just beneath wing with a large testaceous spot; abdomen as long as head and thorax combined.

Male.-Length about $1.5 \mathrm{~mm}$. Similar in color and sculpture to the female; the first joint of the funicle about as long as the pedicel, the second joint distinctly longer than the first; third and fourth joints about as long as first; club slightly longer than joints three and four combined; abdomen apically æneous.

Habitat.-Bangalore, Mysore, India.

Type.-Cat. No. 14346, U.S.N.M.

Many specimens reared from the larvæ of Aspidomorpha miliaris together with specimens of a Tetracampe?, and sent by Mr. Coleman (for whom this species is named) under his number 181 .

TETRASTICHUS OPHIUSA, new species.

Female.-Length about $2.25 \mathrm{~mm}$. Dark blue-green, coxæ metallic, trochanters and femora, except tips, brown, rest of legs testaceous; scape and pedicel brownish-testaceous, rest of antennæ deep brown; joints of funicle elongate, the first about twice as long as the pedicel; club slightly longer than first joint of funicle; face finely lineolate, along inner orbits with scattered large punctures; mesoscutum and scutellum finely longitudinally lineolate, the median furrow on the former and the two furrows on the latter very distinct; metanotum 
reduced to a narrow smooth strip, propodeum with a distinct median, and lateral carinæ, the surface between them finely roughened; abdomen as long as the head and thorax combined.

Male.-Unknown.

Habitat.-Mysore, India.

Two specimens reared from Ophiusa melicerta and sent by Mr. Coleman under his number 37.

Type.-Cat. No. 14350, U.S.N.M.

\section{Subfamily ELACHERTIN \#.}

EUPLECTRUS NYCTEMERE, new species.

Female.-Length $1.75 \mathrm{~mm}$. Black, the soape, pedicel, and legs, including coxæ, testaceous; rest of antennæ light brown; pedicel about as long as joint one of funicle, the latter not distinctly longer than the second joint; third and fourth joints about as long as second; middle lobe of mesoscutum reticulately rugose, at rear medially with one or two longitudinal rugose which extend forward about one-third the length of the mesoscutum; lateral lobes finely rugulose; scutellum basally indistinctly reticulate; first joint of hind tarsi almost twice as long as second, longer spur on hind tibiae not reaching apex of second tarsal joint; abdomen with a large testaceous spot, near base.

Male.-Unknown.

Habitat.-Bangalore, Mysore, India.

Four specimens reared from the larva of Nyctemera lacticinia and sent by Mr. Coleman under his number 189.

Type.-Cat. No. 14347, U.S.N.M.

Easily separated from $E$. manilæ and E. koebelei by the row of pits at the base of the metathorax being covered by the scutellum; $E$. manilæ has the pedicel distinctly shorter than the first joint of the funicle; E. koebelei is larger, more robust, and has the legs distinctly reddish.

\section{Subfamily EULOPHIN $A$ E.}

SYMPIESIS COMPEREI, new species.

Female.-Length about $2 \mathrm{~mm}$. Dark blue-green, the head more bluish, the abdomen basally more greenish, the apical two-thirds of abdomen aenous; legs, except coxæ, scape and pedicel of antennæ, testaceous; rest of antennæ dark brown; face below antennæ finely reticulated with impressed lines, above antennæ these gradually disappearing; pedicel short, hardly half the length of the first joint of funicle, joints 2-4 of funicle subequal in length, slightly shorter than the first, and each about as long as the club; mesonotum, including axillæ and scutellum, with shallow thimblelike punctures those on the median lobe of mesoscutum coarse, those on axillæ finest; metanotum and propedoum smooth, the latter with a median carinæ 
and with curved lateral carinæ the anterior ends turning inward; prepectus with thimblelike punctures; mesepisternum with similar finer punctures; rest of mesopleuræ and the metapleuræ smooth; abdomen as long as the head and thorax together; sheaths of ovipositor exserted.

Male.-Length about $1.5 \mathrm{~mm}$. Similar to the female, but more greenish; the funicle of antennæ light brownish, branches long, reaching beyond apex of last joint of funicle; femora except tips dark brown; abdomen with the basal half whitish and testaceous.

Habitat.-Manila, Philippine Islands.

Three females and six males reared from a leaf miner on Ficus, species, by Mr. George Compere, for whom the species is named.

Type.-Cat. No. 14348, U.S.N.M. 